Malaysian Journal of Social Sciences and Humanities (MJSSH)

Volume 4, Issue 7, November 2019

e-ISSN : 2504-8562

Journal home page:

www.msocialsciences.com

\title{
An Analysis of Classrom Interaction in Speaking Class by Using FIAC System: Teachers Questioning and Feedback (Grade Seven Students in Focus)
}

\author{
Sisay Ayalew Tsegaw ${ }^{1}$ \\ 1Department of English Language and Literature, Bahir Dar Institute of Techology, Bahir Dar University, Ethiopia
}

Correspondence: Sisay Ayalew Tsegaw (sisaya@bdu.edu.net)

\begin{abstract}
The aim of this study was to describe the interaction of teachers and students at primary school levels in speaking class of English foreign classroom. It also aimed at describing how the participants experienced interaction and its level of interactional activities and influences. To carry out the real classroom interaction analysis in speaking class using FIACS technique, qualitative research / qualitative descriptive research was employed for this study, which is qualitative. The results were analyzed using qualitative/Latent content analysis mainly. The targeted schools selected using convenience-sampling technique, but English Language teachers were selected using purposive sampling. Qualitative methods of data collection, such as interviewing, observation, and document analysis were also developed and employed as major tools. The result from these instruments showed that the interaction was still dominated by the teachers as shown from the observation and recording, and the speaking skills input and process haven't been found to have a positive change on their students speaking performance or improvement. Thus, all findings revealed that the teachers were not able to use the appropriate type of classroom language and provide formative feedback that really help in improvement of student's language learning.
\end{abstract}

Keywords: interaction, questioning, feedback

\section{Introduction}

It is possible to presume that education has its own role in the development of oral communication. This implies that early stage educational achievement contributes a lot for their future education and life, and to the economy at a whole. Especially, among several skills, entering school and learning to speak are important early educational milestones for students' long life success. Children's chance for academic and occupational success are limited when foundational speaking skills are not developed. Speaking is one of the most valuable skills developed during childhood, but it is also one of the most cognitively challenging proficiencies to acquire (Lyon, 1998). Teaching young children to speak is the cornerstone of improving educational outcomes and has far-reaching implications.

The researcher believe that without basic oral skills, children are unable to learn and have little chance of succeeding in school. Unless they learn to speak at an early age, children cannot absorb more advanced skills and content those rely on speaking. Children who do not learn to speak in the early grades risk falling further and further behind in later ones, as they cannot absorb spoken information, follow oral instructions, or communicate well in speaking. These challenges, rooted in poor speaking skills, lead to disappointing results and often early dropout from the education system. 
Especially, here in Ethiopian, it is no longer appropriate to call English a medium of instruction; rather it has become a medium of obstruction (Stoddart, 1986). Nowadays teaching is focused on grammar and reading comprehension, which is understandable considering the prominence of these aspects in the matriculation examination. Therefore, it is difficult for our internal and external contexts to speak English in intelligible and comprehensive manner. It is necessary to examine the classroom interaction to have the real picture about the level of the target language.

According to Paul (2003), the students can listen to English at home, read English at home, and even write English at home. But most of them have few opportunities to speak English at home in order that speaking skill should be taught and practiced in the language classroom.

Dealing with speaking practice, Paul also says that the students need to speak, speak, and speak to make the students learn to speak English, each of the students must have many opportunities to speak during the lesson. They need practice, practice, and practice to be able to speak fluently in foreign language requires a lot of practice (Ibid).

When we talk about speaking, we do not mean just saying the words through mouth. It means conveying the message through the words of mouth. This skill is often ignored in some teachers' classes. Learners do not have enough opportunity either in their classes or outside to speak English. Unfortunately, speaking is not an important part of the target population life. In my experience, I have been observing that the level of speaking proficiency decline every year. Especially, students in Ethiopia are generally not able to speak English fluently by the end of secondary schools. Therefore, this study explored the possible poor interactions and causes why students do not speak in and out of classes and find solutions to this problem.

Research indicates that speaking skill is regarded one of the most difficult aspects of language learning. Many language learners find it difficult to express themselves in spoken language. They are generally facing problems to use the foreign language to express their thoughts effectively. They stop talking because they face psychological obstacles or cannot find the suitable words and expressions. According to Cheng et al. (1999), English teaching in primary and secondary education has always put more emphasis on reading and writing in preparation for various types of entrance exams.

As a result, most students have difficulty in understanding and speaking English. The problem with speaking English is even more severe because students lack opportunities to speak English in everyday life and the motivation to speak English in public (Tsou, 2005). In Urrutia \& Vega (2006) research study, the result suggest that speaking is the most difficult skill to develop, students usually present lack of vocabulary, shyness and fear of being humiliated. The authors finding revealed that the majority of students considered that speaking is the most complicated ability to work out.

Some studies pertinent to the factors influencing speaking skill are reviewed. Park and Lee (2005) investigated the connection between second language learners' anxiety, self-confidence, and speaking performance. The results obtained from this research showed that students' anxiety level had a negative relationship to their oral performance. In like manner, Urrutia and Vega (2010) demonstrated that learners' oral performance was influenced by their lack of vocabulary, diffidence, and fear of being despised. It was also indicated that learners' cooperation, self-confidence, vocabulary knowledge, and the class environment encouraged them to improve their speaking skills.

Boonkit (2010) carried out a study on the factors increasing the development of learners' speaking skill. The results represented that the use of appropriate activities for speaking skill can be a good strategy to decrease speakers' anxiety. The results also revealed that the freedom of topic choice urged the participants to feel comfortable, persuaded to speak English, and increased the speaking confidence among EFL learners. Ali Dincer and Savas Yesilyurt (2013) carried out a study towards teachers' beliefs on speaking skills based on motivational orientations. The results of their study indicated that the teachers had negative opinions about speaking instruction though they believed that it was of great significance in speaking skill. The results also revealed that the teachers felt unskilled in oral 
communication to have good interaction with their students though they had various motivational orientations towards speaking English.

Research also indicates that it is necessary to conduct the analysis of teacher-student interaction in speaking class to authenticate other problematic issues. For instance, Wulandari (2011) conducted A Descriptive Study on Teacher - Student Interaction in Speaking Class. The result of this research was the teacher - student interaction consists of classroom activities, language use in speaking class and interaction analysis by using Brown's interaction analysis system. And there were problem faced by the teacher and student, problem faced by the teacher were the students' indolence and the students were less open-minded and the problem faced by the student were the student get difficulty in vocabulary, grammar mastery and pronunciation.

Additionally, Puspasari (2010) carried out on An analysis on the Speaking Classroom Interaction The result of the study shows the percentage of Teacher's talk time in the speaking classroom interactions. Teacher's talk time takes $61,5 \%$, while the student's talk time is $22,8 \%$. The writer also finds some factors which become problem in realizing a good teacher-students interactions. The problems are the students don't want to take a risk, problem in vocabulary mastery, and problems in grammar mastery.

Even though research has been conducted into the teaching of speaking skills internationally, very little has been done in Ethiopia. For example, Fasil (1992) and Tsegaye (1995) have conducted research on speaking strategies employed by secondary schools and college students respectively. Taye (2008), Tesfaye (2007) and Jenenew (2006) studied how oral skills are taught. Taye made a comparative study of televised and non-televised speaking skills teaching techniques. Jenenew made a survey on teachers' and students' role implementation in EFL speaking classrooms. But Tesfaye conducted research on communication strategies utilized by Omo TTI teachers in oral production of English. Nevertheless, none of these studies has revealed what the classroom interactional analysis of teaching speaking skills as a whole is like.

It seems very little research is available on analysis of classroom interaction in language education; the available publications are mostly related with speaking class strategies and attitudes. The present researcher believes that a better understanding of the analysis of classroom interaction in foreign language education can only emerge from the perspective of a multi-dimensional picture of the nature of speaking skills and their perceived impact in improving language skills. In line to this, the present researcher experience has noted that most students are incapable of interacting with teachers. Students have trouble with speaking language skills tasks, students fear during presentation and participation; lack of practice to learn speaking skills inside and outside classroom, and students' poor performance which is at risk unless something is done to upgrade their speaking skills. Moreover, teachers skip to teach speaking skills tasks that actuate the researcher to conduct this study since the researcher believe that this area merits attention and should be researched.

Additionally, the problems, which are going to be explored here, are teacher's questions and feedback in a class. Because two of the most common ways in which L2 teachers engage in interaction with learners is by way of asking questions and providing feedback, and these deserve some consideration (Holland and Shortall, 1997), focusing on them can be expected to show useful findings which will contribute to deeper insights about the ways to improve L2 teaching and learning. Therefore, with all the above insights about speaking skills practice and findings, the present researcher found it extremely appealing to conduct an analysis of classroom interaction in speaking class: Teachers Questioning and Feedback in Grade Seven Students in Focus. Therefore, with all the above insights about projects intervention on reading, the researcher found it extremely appealing to examine the following research questions.

i. What is the extent of interactions of teachers' practice in classroom?

ii. To what extent is there correspondence between teachers' actual practice in classroom settings and researchers' orientation and concern?

iii. What are the practices between the teacher and the students talk time and students' and teacher's characteristics during classroom interaction

iv. What are the type of questions used by teachers to grade 7 students in classroom? 
v. What kinds of speaking inputs are given in grade 7 student textbook?

vi. What kind of feedback provided to grade 7 students in classroom in primary schools?

\section{Literature}

\section{The Role of Teachers in Teaching Speaking Skills}

Learner responsibility can develop if teachers allow more room for learner involvement (Scharle and Szabo, 2000). In the first place your task, like that of any other teacher, is to create the best condition for learning. In a sense, then, you are a means to an end; an instrument to see that learning takes place. But, in addition to this general function, you have specific roles to play at different stages of the learning process (Nunan 1991). However, the problem that commonly faced by the teacher in speaking class is so complicated, such as the students who are mostly afraid to speak up. It is so difficult for the teacher to make them speak, the students are not only afraid to speak up but also they do not have much vocabulary to speak. So, the teacher has important role in encouraging students to speak.

The teacher facilitates communication in the classroom. Teachers should play such of different roles in teaching speaking. In this role, one of the major responsibilities is to establish situations likely to promote communication. Harmer (2001) also states the roles as follow. The first role is prompter. Students sometimes get lost, cannot think what to say next, or in some other way lose the fluency the teacher expects of them. The teacher can leave them to struggle out of situation on their own, and indeed sometimes this may be the best option. However, the teacher may be able to see the activity progress by offering discrete suggestion. The second role is participant. Teachers should be good animators when asking students to produce language. Sometimes this can be achieved by setting up an activity clearly and with enthusiasm. The last one is feedback provider: When students are in the middle of a speaking activity, over-correction may inhibit them and take the communicativeness out of the activity. On the other hand, helpful correction may get students out of the mistakes or errors they have made.

\section{Models of Teaching Speaking}

There are many models of learning speaking. Many authors suggest different models of teaching/learning speaking which have quite similar notions in the authors' list. Some of the models of learning speaking skills or good interactions are main class and study club, conversation on the way, discussion group, and describing picture etc.

A model for Teaching Speaking/Classroom Interaction/Speaking Activities

\begin{tabular}{|c|c|c|c|}
\hline \multicolumn{4}{|c|}{ TEACHER CONTROLLED } \\
\hline \multirow{12}{*}{$\begin{array}{l}\text { A } \\
\text { C } \\
\text { C } \\
\text { U } \\
\text { R } \\
\text { A } \\
\text { C } \\
Y\end{array}$} & & ACTIVITIES & \multirow{12}{*}{$\begin{array}{l}\mathrm{F} \\
\mathrm{L} \\
\mathrm{U} \\
\mathrm{E} \\
\mathrm{N} \\
\mathrm{C} \\
\mathrm{Y}\end{array}$} \\
\hline & A & $\mathrm{C}$ & \\
\hline & Drills & Conversation & \\
\hline & Games & Discussion & \\
\hline & Controlled Conversation & Simulation & \\
\hline & Listening & Games & \\
\hline & Writing & Story-telling & \\
\hline & & Listening & \\
\hline & & Writing & \\
\hline & & Presentation & \\
\hline & B & $\mathrm{D}$ & \\
\hline & Exercises & Discussion & \\
\hline
\end{tabular}




\begin{tabular}{|l|l|l|}
\hline Controlled Conversation & Games \\
Role play & Roles play \\
Games & Project work \\
Questionnaires & Listening \\
Listening & Reading \\
Writing & Writing & \\
\cline { 1 - 2 } & PAIR WORK $\rightleftarrows$ GROUP WORK \\
\hline \multicolumn{2}{|r|}{ LEARNER DIRECTED } \\
\hline
\end{tabular}

Fig 1: Adapted from a model for teaching speaking/classroom interaction (Byrne 1987)

From the above fig, we could infer that Type A activities are focused on accuracy that are controlled by the teacher and done with the whole class. Drills and traditional language games are most present here. Type B activities are focused on correct use of language too, but they are directed by learners and done in pairs or groups (e.g. mini-dialogues). Type $\mathrm{C}$ activities focus on fluency. However, they are controlled by the teacher and done with the whole-class. Whole-class discussions and storytelling are some of them. Type D activities are fluency activities directed by learners and done in pairs or groups which are present the least controlled type of classroom interaction. The role of the teacher varies in each type from an instructor (type A) to a consultant (type D). Byrne's model offers a comprehensive description for classroom interaction, according to which teachers can plan activities alternately focusing on accuracy/fluency or whole-class/group-work organization in order to improve speaking skills.

\section{Inputs and Speaking Activities}

Richards (2013) on RELC Journal mentioned that in language teaching input refers to the linguistic content of a course. It seems logical to assume that before we can teach a language, we need to decide what linguistic content to teach. Once content has been selected it then needs to be organized into teachable and learnable units as well as arranged in a rational sequence. In like manner, Process refers to how teaching is carried out and constitutes the domain of methodology in language teaching. Methodology encompasses the types of learning activities, procedures and techniques that are employed by teachers when they teach and the principles that underlie the design of the activities and exercises in their textbooks and teaching resources. And output also refers to learning outcomes, that is, what learners are able to do as the result of a period of instruction.

There are different kinds of means of presenting inputs in the text book, authentic and inauthentic that students are supposed to read, speak, write and listen. Sentences (contextualized and decontextualized), different kinds of contexts, model dialogues, pictures, role play are dominant inputs. Inputs and objectives in the textbook go with each other. Most of the activities mirror objectives of the tasks. For example, Textbooks are one of the teaching-learning elements of language besides, different textbooks have different contents and approaches; they have also their own target group to address and a goal to achieve. According to Richards and Rodgers (2001) and Ur (1996), textbooks have positive and vital roles to play in the day-to-day language teaching and their importance is increasing from time to time. They are also critical ingredients in learning the intended curriculum. They are a media through which teachers and pupils communicate each other in an effort to forward the teaching and learning process.

\section{Implications for teaching}

Richards(2008) argued that three core issues need to be addressed in planning speaking activities for an English class. The first is to determine what kinds of speaking skills the class will focus on. Is it all three of the genres described in the preceding section, or will some receive greater attention than others? Informal needs analysis is the starting point here. Procedures for determining needs include observation of learners carrying out different kinds of communicative tasks, questionnaires, interviews, and diagnostic testing (e.g., Tsang and Wong 2002). The second issue is to identifying teaching strategies to "teach" (i.e., provide opportunities for learners to acquire) each kind of talk. 


\section{Teaching talk as interaction}

Talk as interaction is perhaps the most difficult skill to teach since interactional talk is a very complex and subtle phenomenon that takes place under the control of unspoken rules (Ibid). In the author's experience, these are best taught by providing examples embedded in naturalistic dialogs that model features such as opening and closing conversations, making small talk, recounting personal incidents and experiences, and reacting to what others say. Similarly, in my experience, the interactional talk is most dominantly carry out by question and answering. In my view, although Role-play activities are another familiar technique for practicing real-world transactions and typically involve the steps of preparing, modeling and eliciting and practicing and reviewing, most of the classroom interaction has been done through reading the dialogue.

One rule for making small talk is to initiate interactions with a comment concerning something in the immediate vicinity or that both participants have knowledge of. Giving feedback (or back channeling) is another important aspect of talk as interaction. It involves responding to a conversational partner with expressions that indicate interest and a wish for the speaker to continue, such as "That's interesting," "yeah," "really," and so on. To practice using back channeling in this way, students can examine dialogs from which feedback expressions have been omitted.

\section{Teaching talk as performance}

Teaching talk as performance requires a different teaching strategy. This approach involves providing examples or models of speeches, oral presentations, stories, etc., through video or audio recordings or written examples. These are then analyzed, or "deconstructed," to understand how such texts work and what their linguistic and other organizational features are. Questions such as the following guide this process:
i. What is the speaker's purpose?
ii. Who is the audience?
iii. What kind of information does the audience expect?
iv. How does the talk begin, develop, and end? What moves or stages are involved?
v. Is any special language used?

\section{Interaction as the key to improving EFL Learners Speaking Abilities}

\section{Interaction analysis}

Richards \& Renandya (2002) explain that the functions of spoken language are interactional and transactional. The primary intention of the former is to maintain social relationships, whereas that of the latter is to convey information and ideas. In fact, much of our daily communication remains interactional. Interaction analysis shares characteristics both with discourse and conversation analysis. It's method of generating data is elicited naturalistic in mode of spoken that use interpretive type of analysis in both linguistic and non-linguistic units of analysis.

In the field of second language acquisition, classroom interaction received rigorous attention from researchers. Classroom interaction takes an important place in the process of language teaching and learning through giving learners opportunities to receive the input that is provided by the teacher, learners or material, which must be understood by the learners in order to make them involved in the classroom task by providing the output. Interaction in English classroom is in the heart of communication in an era of communicative language teaching.

Goronga (2013) asserts that classroom interaction makes the students participating in the teaching and learning process. It means that classroom interaction encourages students to involve. Therefore, teachers need to be aware of to what extent their classroom practices facilitate language learning in reality. The communicative language teaching theory reveals that communication and interaction are 
the purpose of language learning. Interaction plays significant roles in the language classroom since it can increase students' language store, strengthen the social relationship, develop communication skill and build up confidence

Classroom interaction used as building knowledge and improving language skills. By reducing the amount of teachers talk in classroom and by increasing the learners' talk time, it keeps the learners active in the classroom. The importance of interaction has a significant role both in the classroom and out of classroom. Therefore, teachers and students should consider it as an essential part in learning and teaching language skills, especially in speaking class. classroom interaction helps the teachers to manage who should talk, to whom, on what topic, in what language.

Classroom interaction will depend on the dominant type of interaction that is from teacher and students talk. If the teacher gives chance to the students to talk, the classroom interaction will be dominant by students-students. Meanwhile, if the teacher always takes much time to talk in the classroom, the classroom interaction will be dominant by teacher. Ribas (2010) insists that teacher has great influence to make the students involve in classroom interaction. It means that students who are active in the classroom interaction are determined by the teacher's role that give chance the students to talk in the classroom. Equally important, the teacher is the key one to create the classroom interaction. Damhuis and de Blauw (2008) maintain that the teacher's role will affect the quality of classroom interaction. The teachers' role is the teachers have to give chance to the students to talk in the classroom.

\section{Flanders' Interaction Analysis Categories (FIAC)}

The two interaction analysis techniques are Flanders Interaction Analysis System (FIAS) and Social Network Analysis (SNA). Probably the best known of such category systems is the Flanders Interaction Analysis (Flanders, 1970). FIAC is is coding categories of interaction analysis to know the quantity of verbal interaction in the classroom. This technique is one of important techniques to observe classroom interaction systematically (Flander,1970 cited in Subudhi 2011). This system has been used extensively in classroom observation studies (Newman, 2004). It has two main uses. Firstly, it was intended to provide evidence of the differences in teaching patterns that distinguish one teaching style from another and, secondly, it has been used to try to explain differences in learning outcomes associated with different styles of teaching.

Amullah et al. (2008) maintains that FIAC can change the teacher's teaching style. It means that when the teacher knows how much they spend their time talking in the classroom, they will know their quality in making the students active in the classroom. Making the students participate at the classroom interaction, the teacher has to create and design materials that make classroom interaction is dominant by students since students-centered is required in Communicative Language Teaching (CLT).

The FIAC consist of 10 categories of communication, seven used when the teacher is talking, two used when a pupil is talking, and one when there is silence or confusion). An observer using the system makes timed observations, usually every three seconds, and categorises the behaviour, which he/she observes at each point into one of ten categories. These categories are shown below.

Table: Flanders' Interaction Analysis Categories (Fiac)

\begin{tabular}{|l|l|l|}
\hline \multirow{5}{*}{$\begin{array}{l}\text { Teacher } \\
\text { Talk }\end{array}$} & $\begin{array}{l}\text { Accepts feeling: accepts and clarifies the feelings of the students in a } \\
\text { non-threatening manner. Feelings may be positive or negative. } \\
\text { Influedicting and recalling feelings are included. }\end{array}$ \\
\hline $\begin{array}{l}\text { Influence } \\
\text { behaviour. Jokes that release tension, not at the expense of another } \\
\text { individual, nodding head or saying 'uh huh?' 'good' or 'go on' .etc are } \\
\text { included. }\end{array}$ \\
\hline $\begin{array}{l}\text { Accepts or uses ideas of student: clarifying, building, or developing } \\
\text { ideas or suggestions by a student. As teacher brings more of his own } \\
\text { ideas into play, shift to category five. }\end{array}$ \\
\hline
\end{tabular}




\begin{tabular}{|c|c|c|}
\hline & & $\begin{array}{l}\text { Asks questions: asking a question about content or procedure with the } \\
\text { intent that a student may answer. }\end{array}$ \\
\hline & & $\begin{array}{l}\text { Lectures: giving facts or opinions about content or procedures; } \\
\text { expressing his own ideas; asking rhetorical questions. }\end{array}$ \\
\hline & Direct & $\begin{array}{l}\text { Gives directions: directions, commands, or orders with which a student } \\
\text { is expected to comply. }\end{array}$ \\
\hline & Influence & $\begin{array}{l}\text { Criticises or justifies authority: statements, intended to change student } \\
\text { behaviour from non-acceptable to acceptable pattern, bawling someone } \\
\text { out; stating why the teacher is doing what he is doing, extreme self- } \\
\text { reference. }\end{array}$ \\
\hline & & $\begin{array}{l}\text { Student talk - responses: talk by students in response to teacher. Teacher } \\
\text { initiates the contact or solicits student statement. }\end{array}$ \\
\hline $\begin{array}{l}\text { Student } \\
\text { Talk }\end{array}$ & & $\begin{array}{l}\text { Student talk - initiation: talk by students which they initiate. If 'calling } \\
\text { on' student is only to indicate who may talk next, observer must decide } \\
\text { whether student wanted to talk. If he did, use this category. }\end{array}$ \\
\hline & & $\begin{array}{l}\text { Silence or confusion: pauses, short periods of silence and periods of } \\
\text { confusion in which communication cannot be understood by the } \\
\text { observer. }\end{array}$ \\
\hline
\end{tabular}

\section{Teachers Questioning and Feedback in Classroom Interaction}

Questioning has been in the core of philosophy and education, ever since Socrates decided to criticize and question almost everything. Even though questioning is often overlooked when developing teaching and learning activities, it is as critical to teaching as air is to breathing (Quigley, 2012). In recent years, a much greater role has been attributed to interactive features of classroom behaviors, such as turn-taking, questioning and answering, negotiation of meaning, and feedback (Richard and Lockhart, 1994). The background of this lies in the fact that second language learning is a highly interactive process (Ibid) and the quality of this interaction is thought to have a considerable influence on learning(Ellis cited in Richards and Lockhart).

Teachers' questioning is one of the most frequently practiced teaching techniques in the classroom, which improves the students' participation in classroom interaction and helps in enhancing the students' understanding of a topic. Considering the significance of questioning in developing students' knowledge, Galls stated that teachers spend more than a half of classroom time on questioning and answering (Richard, 1996). However, a number of factors such as wait time, socio-linguistics and learning environment can influence the effectiveness of teachers' questioning (Tienken et al., 2009).

Much of the work on questions has centered on developing taxonomies to describe the different types (Ellis, 1994). Several ways of distinguishing on question types have been developed by researchers in the seventies (e.g., Kearsley, 1976) and eighties (e.g., Hakasson \& Lindberg, 1988) and they are still being developed. For instance, As Long \& Sato (1983) cited in Ellis (1994), it has seven sub-categories under two headings of types. The first one is Echoic Types that comprise comprehension checks, clarification requests, and confirmation checks. The other one is Epistemic Types, which include referential, display, expressive, rhetorical. The categories of those questions here are based on the following:

i. Are questions simply repeated? If so, are they repeated more slowly/with different (unnatural?) intonation or stress patterns?

ii. Are they rephrased?

iii. Does the teacher employ additional questions to clarify the initial one

iv. How long is the wait-time?

On the contrary, Gabrielatos (1997) suggested a categorization of the questions frequently used by instructors. He distinguished between the following types of pedagogical questions: 1) Yes/No: questions that require only 'yes' or 'no' answer; 2) Open-ended: questions that will elicit more 
language; 3) Convergent (closed questions that elicit a single answer; and 4) Divergent: questions that allow the students to express views, opinions or alternatives. Similarly, in language classes, the teachers have primarily the role of providing negative feedback, a form of error correction, and positive feedback that shows teachers' approval or acceptance of students' production.

Winne and Butler (1994) as quoted in Hattie and Timperley (2007) summarized the concept, as feedback is information with which a learner can confirm, add to, overwrite, tune, or restructure information in memory, whether that information is domain knowledge, meta-cognitive knowledge, beliefs about self and tasks, or cognitive tactics and strategies. Teachers are expected to provide feedback to students about their previous achievements/errors and corrective actions in future. If done well, feedback can be very powerful. Effective feedback gives students the information necessary for understanding where they are in their learning and what they need to do next (Brookhart, 2008).

Once the students understand what to do and why, most of them will be motivated to invest effort in work (ibid). After numerous researchers had provided lists of feedback types. one of the most frequent and simplest ways of the categories are: positive and negative feedback, and specific feedback. When I read various scholar works, no persuasive conclusion has been reached yet. For instance, Nunan (1991) says that the following key questions on treatment of errors are still controversial:

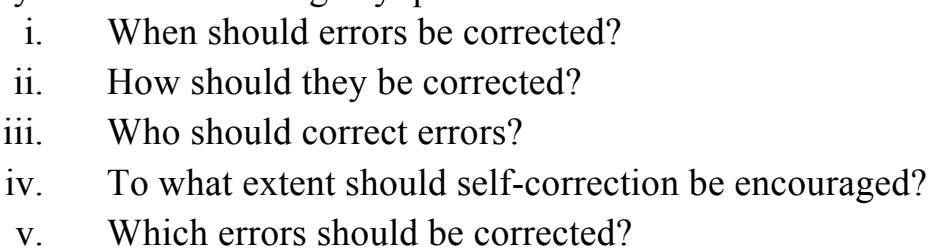

To sum up, Interaction Analysis (IA) is an analytical observation scheme that gives an insight into what a teacher does while teaching. It is a systematic observation that represents a useful means of identifying, studying, classifying and measuring specific variables as the teacher and his/her students interact within instructional learning situation. It uses a system of categories to encode and quantify classroom behaviour of teacher and students. Moreover, Flanders' interaction analysis system is an observational tool used to classify the verbal behaviour of teachers and pupils as they interact in the classrooms that make possible significant insights into the analysis and improvement of instruction.

If students won't talk or say anything, we should take in account that we learn to speak by speaking. One way to tackle this problem is to find the root of the problem and start from there. The mentioned factors in the above have an important role in developing learners' speaking skill. The factors make learners less self-confident and less comfortable in their speaking classes. These problems are not new nor are the solutions offered above. Teachers all over the world continue to face the same hurdles, but any teacher who has overcome these difficulties and now has a large class of energetic students talking and working in English in groups together will tell us it is worth all the trial and error and effort at the outset.

In conclusion, speaking is one of the central elements of communication. Teaching speaking constitutes a central issue in second language learning because it contributes to success in the acquisition of the second language. Teachers play an essential role in the acquisition of this skill in that they are in charge of promoting meaningful communication in the classroom. It needs to devote more time both to teaching activities and to the teaching of speaking. In EFL teaching, it is an aspect that needs special attention and instruction. In order to provide effective instruction, it is necessary for teachers of EFL carefully examine the factors, conditions, and components that underlie speaking effectiveness.

\section{Conceptual Framework}




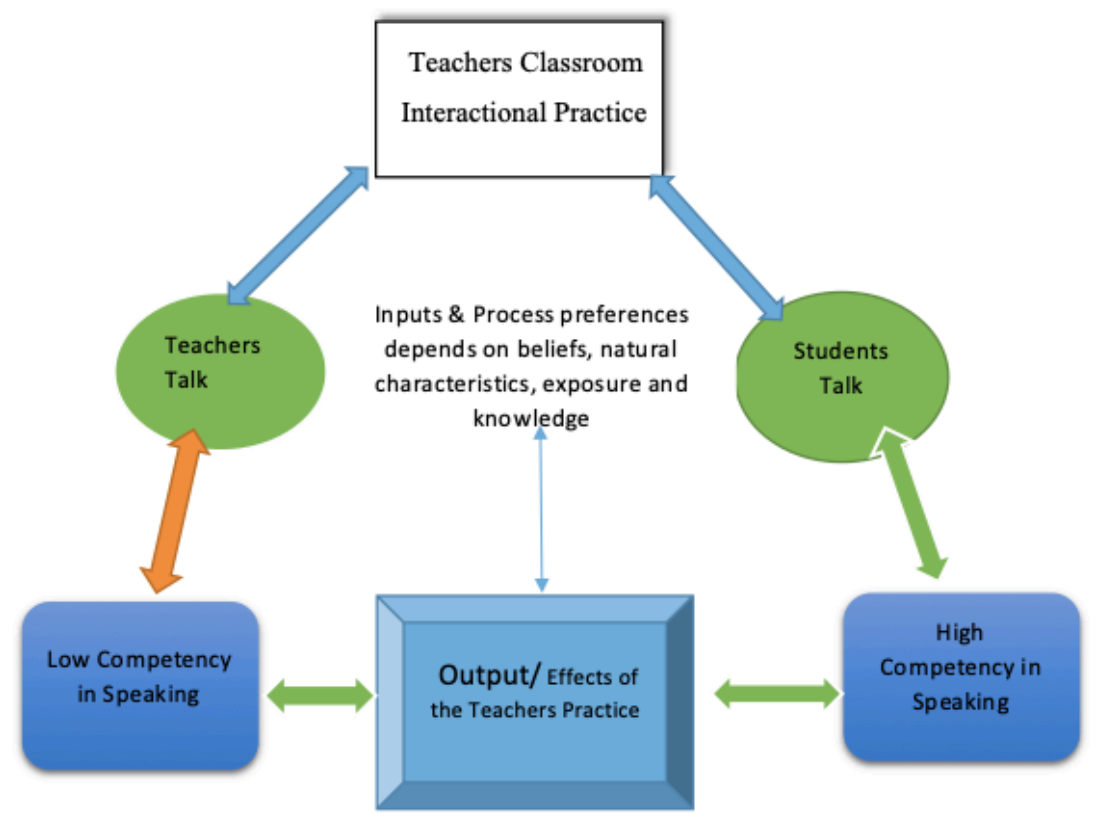

As we can see, I developed this conceptual framework based on the theoretical issues, which are discussed in the previous sections in order to have a holistic view about classroom interaction during speaking sections.

\section{Method}

\section{Research Design}

The purpose of this study was to describe the interaction of teachers and students primary school levels in speaking class of English foreign classroom. It described how the participants experienced interaction and its level, what types of interactional activities and influences, what they felt about it, what motivated them, and how they experienced difficulties, failures, and success. This study looked deep into classroom real phenomenon, that was, classroom interaction. It tried to understand the participants and help their problems. To carry out this analysis of classroom interaction in speaking class using FIACS technique, qualitative research / qualitative descriptive research/ employed for this study.

This design was used because it was the suitable approach in researching about real classroom interaction. It was in line with this research that it would observe the questioning and feedback between the teacher and the student(s) in the classroom. It would go deeply to show what happens in those particular classrooms setting. The goal of qualitative descriptive studies is a comprehensive summarization, in everyday terms, of specific events experienced by individuals or groups of individuals (Lambert, 2012). A qualitative descriptive approach needs to be the design of choice when a straightforward description of a phenomenon is desired. It is an approach that is very useful when researchers want to know, regarding events, who were involved, what was involved, and where did things take place.

\section{Sampling}




\section{Population and Sampling}

Sampling is an important component of any study because of the significant impact on the quality of the findings. So, it is essential to have sampling procedures which are fit for the study purpose. The sampling procedure for selecting English language teachers and for each selected primary school was purposive sampling. According to Lambert (2012), regarding the use of sampling in a qualitative descriptive design, virtually any purposeful sampling technique may be used. Like any other qualitative research design, the goal is to obtain cases deemed rich in information for the purpose of saturating the data. Of basic importance is for researchers to be able to defend their sampling strategies to meet the purposes of their studies.

The participants of the present study included two teachers who taught English in grade 7 classes of two different schools, together with their students in EFL speaking classes at Atse Sertse Dingel and SoS schools for interview and observation purposes. Each teacher had several years of teaching experience. The researcher wanted to study at elementary schools because later problems come from the lower grade. The study was conducted at these primary schools in 2018. These schools were selected for the study using convenience-sampling technique. Convenience sample relies on available subjects-those who are close at hand or easily accessible (Berg, 2001). Therefore, the schools were selected mainly because of their proximity, variety (public and private schools) and schools alacrity.

\section{Data Collection Instruments}

In recent years, the field of education has seen an increase in the number of qualitative studies that include observation as a way to collect information. Qualitative methods of data collection, such as interviewing, observation, and document analysis, have been included under the umbrella term of qualitative design in recent years. Data collection of qualitative descriptive studies focuses on discovering the nature of the specific events under study. Thus, data collection involves minimal to moderate, structured, open-ended, individual or focus group interviews, observations, and examination of records, reports, photographs, and documents (Lambert, 2012).

During collecting data, the researcher used three techniques. Firstly, to obtain the necessary data, observation was employed as the major tool. Observation is an activity in collecting data by observing source of data to get data needed. Sutopo (2002) describes observation as a technique used to get the data from the source of data as event, place, and things or documents. Creswell (2012) also emphasizes that observation is the process of gathering open-ended, firsthand information by observing people and places at a research site. As a form of data collection, observation has both advantages and disadvantages. Advantages include the opportunity to record information as it occurs in a setting, to study actual behavior, and to study individuals. So, the researcher conducted an observation as an observer.

Secondly, to consolidate the data to be gathered through observation, Semi-structured interview used for the observed classroom teachers. Interviews in qualitative research provide useful information that permit to describe detailed information. The researcher conducted One-on-One Interviews which is a data collection process in which the researcher asks questions to and records answers from only one participant in the study at a time. Finally, document (grade 7 English textbook) of the selected grade level was used to analyze curricular inputs for speaking skills. This a wide range of data collection instruments ensured that enough data could be gathered and in ways that are complementary to each other. Documents represent a good source for text (word) data for a qualitative study. They provide the advantage of being in the language and words of the participants, who have usually given thoughtful attention to them. They are also ready for analysis without the necessary transcription that is required with observational or interview data (Ibid).

\section{Method of Data Analysis}


After administering research tools, data were collected and organized. To analyze the data collected through the data collection instruments, qualitative methods of data analysis was carried out for the data which obtain from observation, interview and document. For these instruments, qualitative content analysis (Latent content analysis) was employed. Latent level qualitative content level analysis concerns an interpretative analysis of the underlying deeper meaning of the data (Dornyei, 2007).

\section{Procedures}

At first I went to different schools to observe. The main reason I went was to decide the date of granting and observing. The data were collected through unstructured observation in the second week of May 2018 E.C in 3 grade 7 English lessons. The researcher conducted 3 observation and interview from 10-14/06/2019 in Atse-Serste Dengel and SoS schools. For data collection purposes, an audiorecorder was used to record the data of the teacher and student talk in the teaching and learning process. The verbal interactions which are going on in the teaching and learning process are usually very fast and complex. Thus, it is difficult to observe the verbal interaction without using a recorder.

By utilizing the recorder, the collected data are more accurate and the data collection becomes more precise. Then the data collected from the recording were transcribed into a written form to facilitate the researcher in analyzing them. Both the observation and the interview were written in a descriptive and narrative report. To keep the validity of the transcription into a written form, the researcher played back the recorder numerous times during the transcription. In similar fashion, the three teachers were recorded during interview since this was conducted to get information from the teacher. It was done when the data obtained from the observation was considered not clear or insufficient.

In this case, the interview was aimed at complementing the data collected from observation and verifying the trustworthiness of the data before and after the observation. Before the observation, it used to know the teachers understanding, believe, opinion, experience...etc. In this study, document analysis was also used to complement the data which were not covered in the recording such as the activities, inputs, techniques during the teaching and learning process. The document that has been taken for analysis was grade 7 English textbook and all the speaking tasks that used as a bridge between students and teachers. Lastly, the collected data were coded according to the themes.

\section{Data Analysis and Discussion}

This section reports the results of class observation that tells what each of the two teachers and their students did in their observed classes. The percentages were worked out based on records of what they did and the frequencies of each talk, then average numbers of each teacher and the students were calculated.

\section{Teachers and students level of interactions}

When the researcher analyze the observed lesson transcripts, T-chart was used to record the data about teacher talk and student talk based on the transcript utterances that contain or convey meaning.

Table 1: The level of interactivity of teachers and students in speaking lesson

\begin{tabular}{lllll} 
Teacher & $\begin{array}{l}\text { Teacher Talk } \\
\text { Number of } \\
\text { Utterances/grids }\end{array}$ & $\begin{array}{l}\text { Teacher talk } \\
(\%)\end{array}$ & $\begin{array}{l}\text { Student Talk } \\
\text { Utterances/grids }\end{array}$ & $\begin{array}{l}\text { Student } \\
\text { talk }(\%)\end{array}$ \\
\hline T1 & 508 & 81.02 & 119 & 18.98 \\
\hline T2 & 385 & 77 & 115 & 23 \\
\hline
\end{tabular}

As Table 1 indicates, teacher talk was dominant in most of the class time and student talk was less dominant. Teacher 1 devoted class time to talk averagely $81.02 \%$. Similar result is also obtained from 
the record of classroom interaction between Teacher 2 and his students in which $77 \%$ of the class time was used to talk. Compared to teacher 1, teacher 2 talked less than teacher 1. It means that the students received more opportunity to talk from the class time with the percentage of $23 \%$ in teacher 2 classroom, whereas the students in teacher 1 's classroom had less chance to talk with an average percentage of $18.98 \%$.

Table 2: The result of the FIAC (From extract)

\section{FIAC System Results}

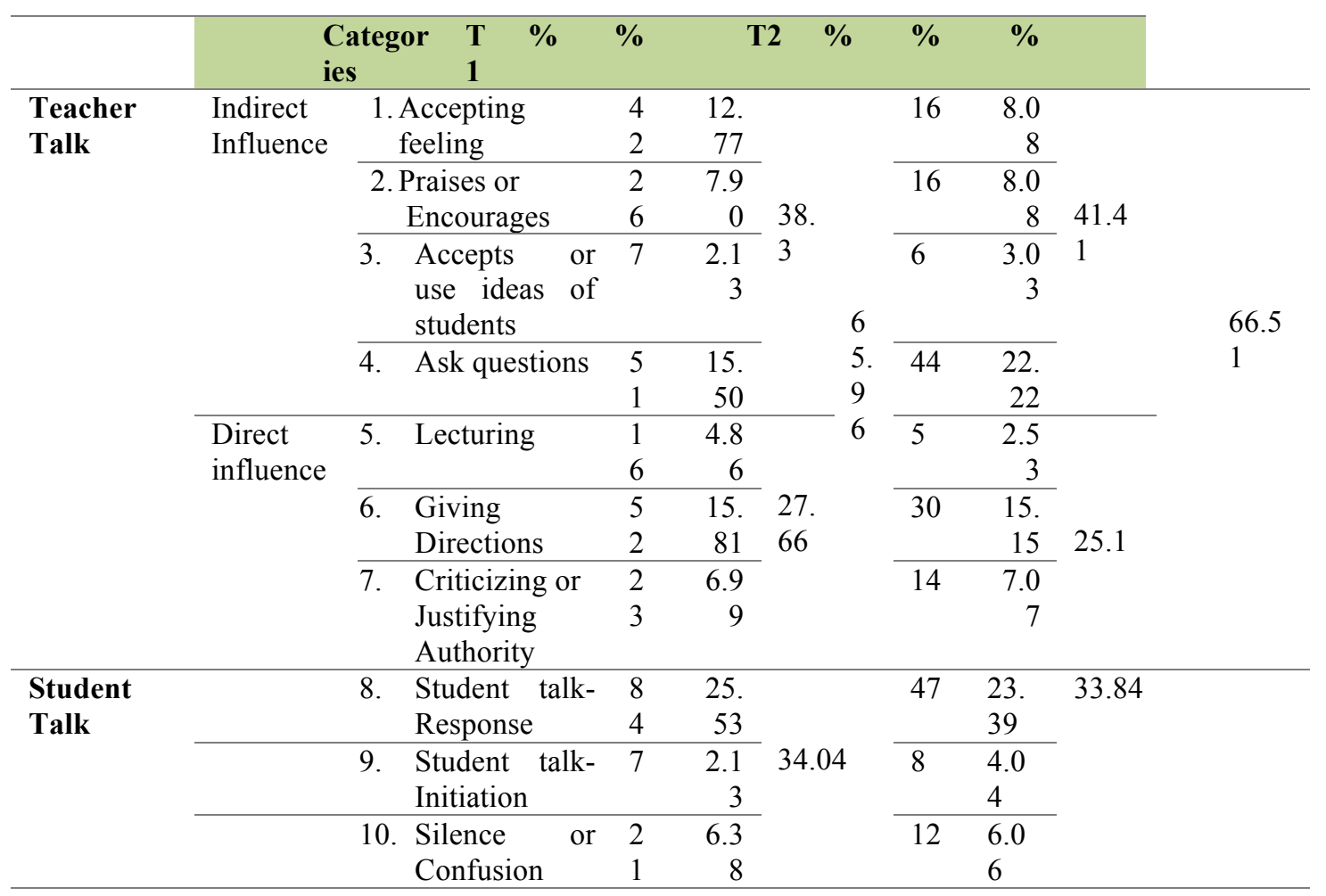

The amount of speech of the teachers and students in the classroom teaching reflects the proportion of classroom time, which to a large extent reveals who holds the initiative in the classroom. As can be seen in table 2, compared to the teachers influence, both teachers had highly indirectly influence students interactions that are $41.41 \%$ and $38.3 \%$ for $\mathrm{T} 2$ and $\mathrm{T} 1$ respectively. From the table, the pattern of teacher talk that was dominant is giving directions. Meanwhile, based on the patterns of student talk as stated in FIAC System, only one category was occupied by student talk, namely: student talk response with a specific and limited range of answer (25.53\%). To sum up, above $65 \%$ teachers talk dominated the speaking lessons.

The following figures also show that how both teachers were dominated students in the speaking sessions based on FIACS. While the teacher's talk increases greatly, the chances for students' expressions are reduced accordingly, which predicts a pattern of less interactions between the teacher and the students that hinders students not to speak in such habits. 

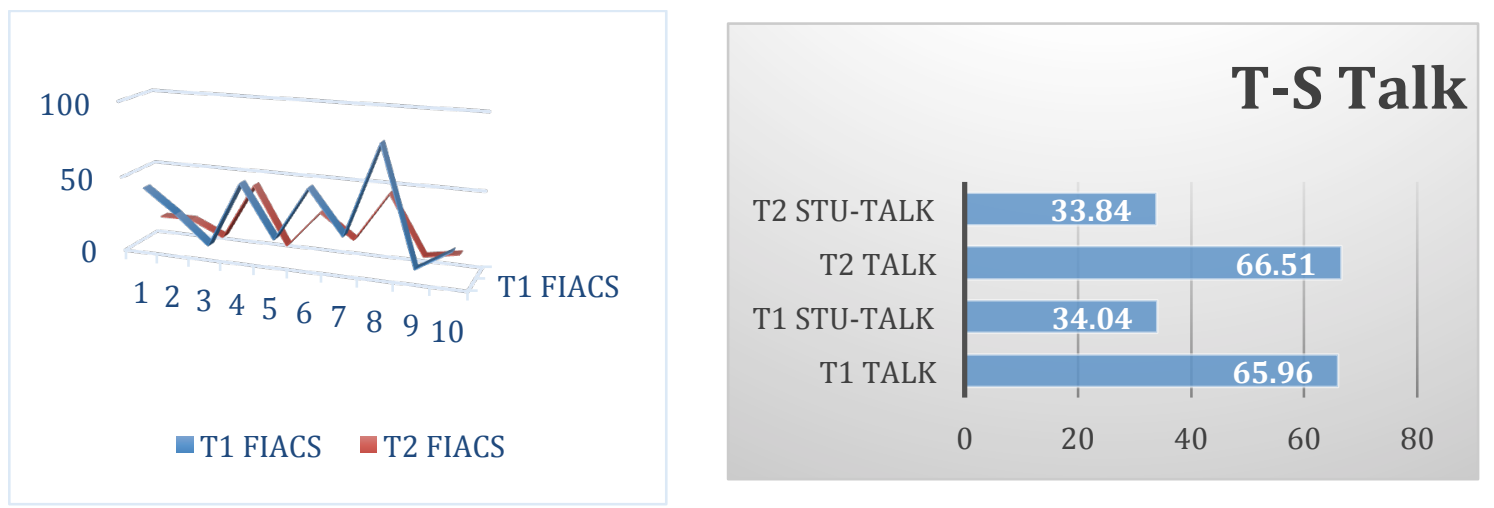

Fig. Simulated curve and graph chart of teacher talk and student talk percentage

\section{Type of questions}

Table 3: Type of questions used by teachers and students during speaking lessons

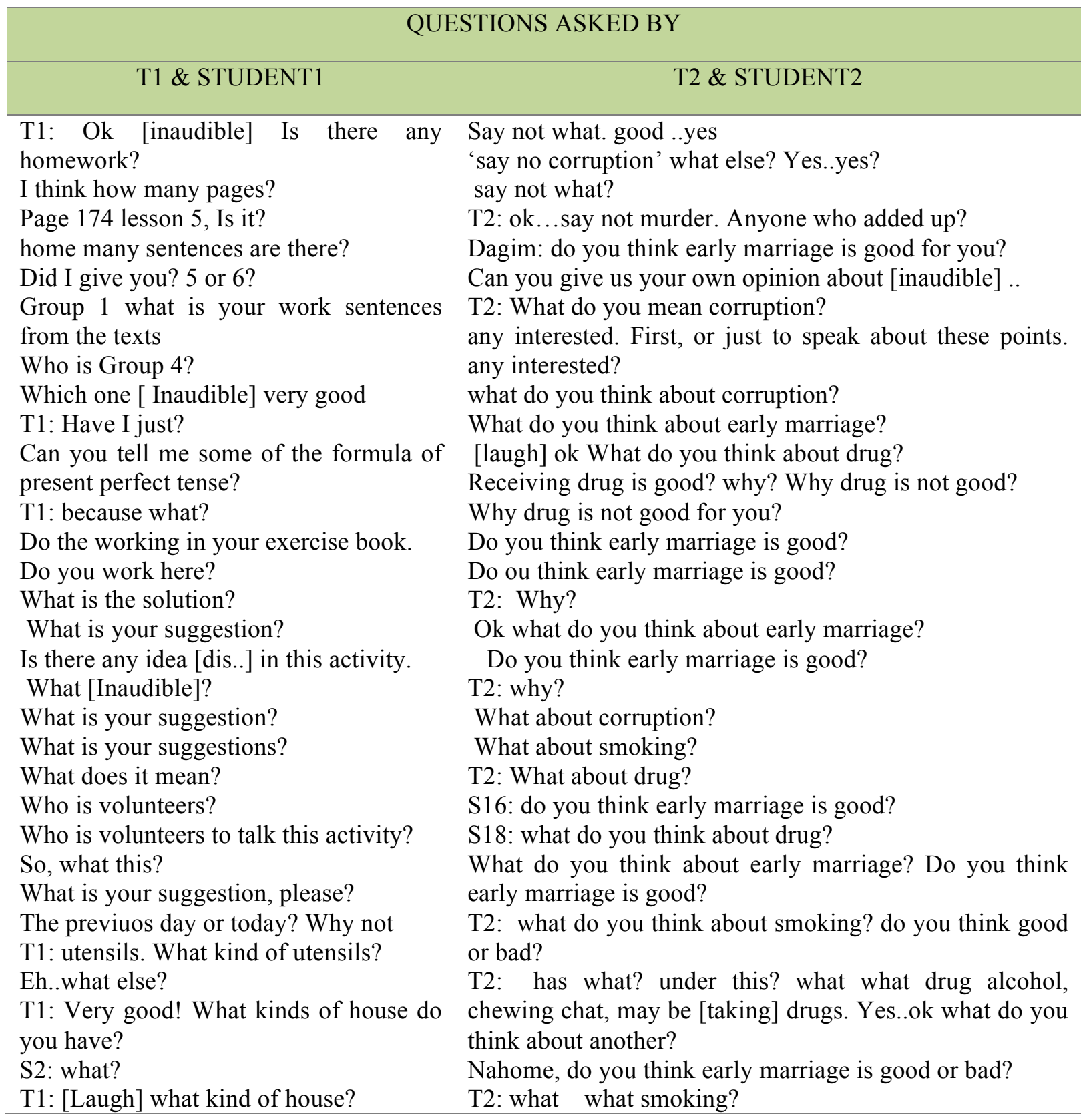


What else? What else?

Group fourth...group 4? Group 2 ..ok ya.... Can you tell me something?

Can you give something?

Can you give suggestions?

T1: their clothes...your family or your self? Cloth

Can make a sentence from the table?

this group ..hallo..yes..can you make 1 sentence?

T1: Okilo or Akilo..Akilo

Can you tell me the meaning of yet?

What is the part of the tenses? The structure yet

T1: Is it a negative form or positive? Yet

This group. Yes! Can you make 1 sentence...good

Do you know the word kitchen?

What is the meaning of kitchen in English?

Your friend..ya ..can you help her?

I think there is one example. Is that it is very simple?

S21: have you seen the house keeper?

S22: How does...how does does switched open the radio?

T1: switched ...ya ... the word switch ok number what?

Ya..ahaa....ya...can you make one sentence the last questions

Did you work? The grammar? The vocabulary?
T2: sosena ......ok sosena ..what o you think about early marriage?

T2: Alright1 What do you think about drug in general?

T2: what do you mean drug?

Ok First, let me just define drug? How can you just define drug?

T2: which drugs are important for our body?

what do you think about corruption?

T2: In what way corruption is ok? by...for the givers ....for the receivers

S22: what do you think about drugs.

S24: what do you think about corruption?

S24: What do you think about smoking?

T2: what about corruption? Is it good or bad?

T2: And what about drugs? drug to mean alcohol? chat may be drug? different items...ok. What do you think about them?

T2: For example, I drink alcohol? is it good or bad?

T2: bad. When alcohol is bad? when? sometimes it might be good. Do you mean that ..ok...beer industry should be stop. working if drug is bad? yes you agree? you agree? If drug for example, alcohol is one part drug therefore let [..] open [..] good. Therefore, every beer industry should stop working. Do you agree? Yes...Do you agree? No! Why? Yes

As the above table shows that T2 questions can facilitate the speaking lesson than T1's questions. As the researcher have already observed in $\mathrm{T} 1$ class, students were kept quiet by listening plenty confirmation questions. This study also categorized the above teachers' and students questions according to Long \& Sato taxonomy as follows.

Table 4 demonstrates that $43.48 \%$ of teacher 1 frequently asked confirmation check questions that elicit Yes/No answers, one-word responses and/or answers that rely almost completely on memory. On the contrary, $36.36 \%$ of clarification questions were asked in T2 speaking lessons even though $34.09 \%$ also depicted in line with confirmation check questions. In addition, in epistemic type of questions, display questions took $6.52 \%$ and $11.36 \%$ for $\mathrm{T} 1$ and $\mathrm{T} 2$ respectively. In addition, as can be seen in the class transcript, in the classification of question types, both teachers did not employ additional questions instead they repeat the same questions.

Table 4: Teachers question types

\begin{tabular}{lllllr}
\hline \multirow{2}{*}{ Types } & Sub-category & \multicolumn{5}{c}{ No of Questions } \\
\cline { 3 - 6 } & & T1 & $\%$ & T2 & \multicolumn{1}{c}{$\%$} \\
\hline \multirow{2}{*}{ Echoic } & Comprehension checks & 9 & 19.57 & 1 & 2.27 \\
\cline { 2 - 6 } & Clarification requests & 9 & 19.57 & 16 & 36.36 \\
\cline { 2 - 6 } & Confirmation checks & 20 & 43.48 & 15 & 34.09 \\
\hline \multirow{2}{*}{ Epistemic } & Referential & 4 & 8.7 & 4 & 9.09 \\
\hline
\end{tabular}




\begin{tabular}{llllr} 
Display & 3 & 6.52 & 5 & 11.36 \\
\hline Expressive & 1 & 2.17 & 2 & 4.55 \\
\hline Rhetorical & 0 & 0 & 1 & 2.27
\end{tabular}

\section{Feedback}

The other serious issues that the researcher's tried to explore is about what kind of feedback teachers provide to students. Almost zero number of negative feedback was given by T2. The teacher accepted students feeling and encouraged students to speak in positive manner. For instance, look the following extracts.

\section{Extract 1(Accepting)}

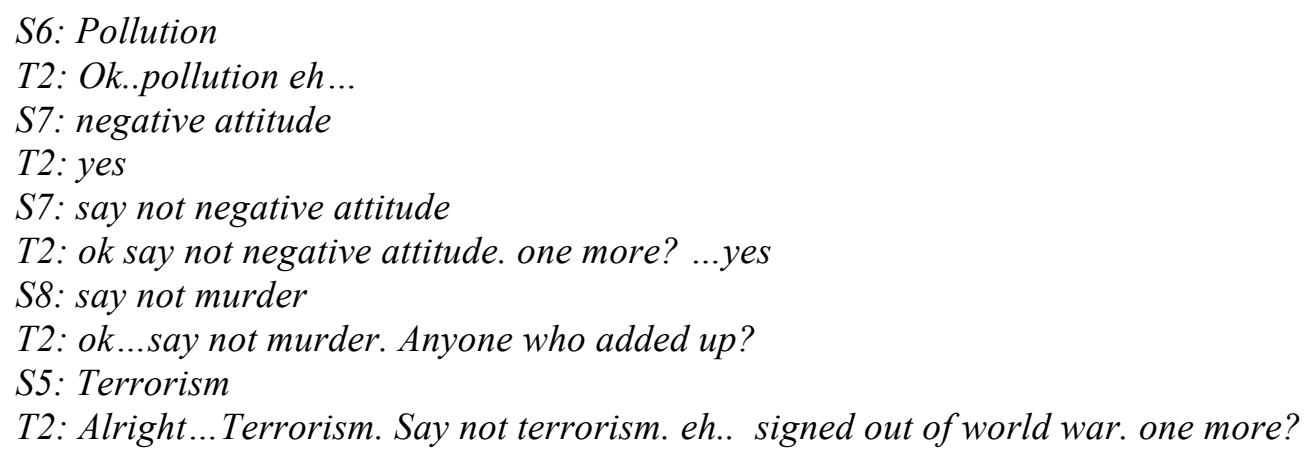

\section{Extract 2 (praise and encourage)}

T2: Ok ...one more 1.... one more any interested. Emenet....ya com on? Ok what do you think about early marriage?

Do you think early marriage is good?

S15: I don't think early marriage is good

T2: why?

S15: because lateral [in...]. I think the agent is not grante.....[inaudible].

T2: Alright! What about corruption?

S15: I think corruption is not good [in audible]

T2: nice! What about smoking?

S15: I think it ... \{ Inaudible]

T2: What about drug?

S15: [Inaudible]

T2: Excellent [clapping] . ok ..any interested. Bemnet ..you come up, please? Ask her any question that you want Euel ask him

S16: do you think early marriage is good?

s17: I think early marriage is becuae corruption in [inaudible] of the next generation and cause the various diseases while making good. [inaudible]

T2: Nice! Sosina ask him! Loudly speaking, Please! Turn up your voice?

\section{Extract 3(Accept, praise and encourage)}

On the other hand, T2 gave very little verbal feedback and this result clearly appears in the FIAC system. In many cases, instead of saying or giving feedback while the students give response, the teacher always say 'Very Good'. This repeating of word makes the teacher to get less emphasis for his positive verbal feedback. For instance, from the transcripts, the word 'Very Good' was frequently used (i.e in the typescripts, I have counted 47 utterances).

\section{Extract 4}




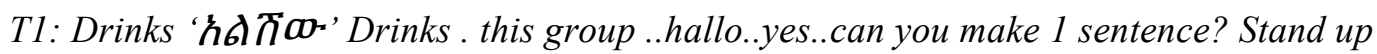
Ok...ya ...please make it one sentence

S14: we has

T1: we has ..very good

S14: ...my mother drink yet

T1: Very good, very good. That is the talking style is she is right. [laugh]. Yes...right..yes ..hello am going ...yes

S15: Ekilo has

T1: Okilo or Akilo..Akilo

Ss: yes

T1: ah ... akilo is a person

S15: Akilo had just swept the compound.

T1: Very good. Yes..you ..Hello ..hello ..yes. good. Hurry up ... Hurry up! Hurry up!

T1: Umh....Hello..yes ... what? Ahee...you need to catch the idea Aha... why not ask your friend? Her ...ya ....it is difficult. You are grade 7. Imagine. Very good..yes.

The researcher also recognizes that $\mathrm{T} 2$ use words frequently that inhibits communication by demotivating students. The following extracts show this.

\section{Extract 5}

S13: He have already drinks [the food]

T1: Drinks' 'Drinks . this group ..hallo..yes..can you make 1 sentence? Stand up Ok...ya ...please make it one sentence

S14: we has

T1: we has ..very good

S14: ....my mother drink yet

T1: Very good, very good. That is the talking style is she is right. [laugh]. Yes...right..yes ..hello am going ...yes

S15: Ekilo has

T1: Okilo or Akilo..Akilo

Ss: yes

T1: ah...akilo is a person

T1: You are a dead man. Hello. Iam great sorry. He is anew comer. Why don't you give some Excellency for him?

T1: .....what? What? What?

T1: Who is Bereket? The absence students.

T1: This group can tell me something that is the oldest. The old of boy when you participate like your friend like Euel. Girls and boys are the same or congruent. Why not make up like your friend

T1: you need to catch the idea Aha ... why not ask your friend?

T1: ....it is difficult. You are grade 7. Imagine.

T1: don't say h' '. This is Amharic word, why not raise your hand and teacher or you can say me.

T1: Don't say like that...

T1: what? What? what? what?

\section{Activities/Inputs}

Table 5: Grade 7 English student textbook's speaking skills activities/inputs

\begin{tabular}{llll}
\hline Page No & Activities & No. of tasks & \\
\hline $\mathbf{1}$ & Act conversation & 1 & Group \\
\hline $\mathbf{1 9}$ & Discussion questions & 1 & partner \\
\hline
\end{tabular}




\begin{tabular}{llll}
\hline $\mathbf{4 9}$ & Describing pictures & 1 & partner \\
\hline $\mathbf{4 9}$ & Discussion questions & 1 & partner \\
\hline $\mathbf{6 5}$ & Describing pictures & 1 & partner \\
\hline $\mathbf{6 5}$ & Discussion questions & 1 & partner \\
\hline $\mathbf{7 7}$ & Describing pictures & 1 & partner \\
\hline $\mathbf{1 0 1}$ & Describing pictures & 1 & Group \\
\hline $\mathbf{1 1 5}$ & Describing pictures & 1 & Group \\
\hline $\mathbf{1 2 9}$ & Describing pictures & 1 & partner \\
\hline $\mathbf{1 4 3}$ & Describing pictures & 1 & partner \\
\hline $\mathbf{1 5 9}$ & Describing pictures & 1 & partner \\
\hline $\mathbf{1 7 1}$ & Describing pictures & 1 & partner \\
\hline Total & & 13 & \\
\hline
\end{tabular}

As we can see from the above table, only 13 activities are found in the student textbook. The activities and the methods are also cyclic in each 12 chapters.

\section{Summary of the teachers Pre and post observation Interview}

The teacher asked about the most important skills for his students, and replied the following which indicated about speaking skills.

"Writing most of the time the teachers...ok the teacher is writing on the blackboard.

Now and then the whole students are what can I say very several time to write but they didn't speak. They didn't communicate within each other. It is so difficult this is what can I say that based on speaking".

Before the observation the teacher mentioned the following as the main reason related to speaking skills problem.

I think so this is the first base of starting point from grade one. I think so there is difference between the government school and the privatization schools. Most of the time is most of the teachers themselves. They didn't speak most of the time.

When you see not only in 1-4 grades; why not 9 upto 12 grades. That is the only of in Amharic. It is so difficult.

After the observation, the researcher asked the teacher why poor interaction occurred when he taught the speaking lesson. The teacher replied as the class size "...the class size the class size.. how many students are there in the class?...." However, the teacher enjoys in teaching speaking. He says ..." yes, of course! This is international language as it is as a teacher I should be..."

The teacher also give emphasis for fluency from different aspects of speaking skills. The following extracts confirmed this.

"Accuracy it is necessary the half of the idea but not...but not in Africa...[what can ..] because the students will be able to speak without any grammar. It is so like it ...fluency without a grammar. Why not speaking like this' I are a student' why not. This is that based on fluency. Fluency is necessary easier than accuracy".

The teacher felt the following about the observed speaking lessons.

'I think more that area because there is a new comer and then that based on grade 7 the students should be able to talk something that is short period of time. But most of the students cannot participate.............And then, today lesson that based on speaking...then you can give different style that regarding speaking. When you see my lessons time, there are different types of mixtures...some of the grammar, some of the speaking. It is so difficult for students....."

The researcher also asked about to what extent the teacher achieved his objectives. The teacher conception is quite different with the above findings of interactional analysis. "T1: ya...I think 
...today that related to the annual daily lesson plan focused on speaking. I think most of 85 or $83 \%$ speaking lessons and the students can achieve what can I say my lesson today."

It seems that the teacher have never adapted additional inputs that offer for speaking skills as the researcher learned from the following extracts. “......when I have finished, umm..some lesson or the unit and then I give extra information, extra grammar, and assessments, that regard to the whole unit...."

The researcher also asked the teachers about what did they learn about speaking on their own teachertraining course? They replied that to tell the truth, they don't really remember what actually learned on their own teaching training course. In line to this, the teachers show their highly enthusiasm about training as the following extracts show on the question do you need in-service training in order to develop opportunities towards teaching and evaluating speaking skills? ": ....RIGHT...YOU ARE!!!!! Ya! Ya! This is my questions but I didn't tell you! Ya! It is what can I say? The...opportunity I like it......... Why not find? Why not find to give information that based on in English? Can I ask Bahir Dar University? He said my friend......'.

Similarly, both teachers were asked about how they help students who have problems with speaking. It is contradictory when the researcher relate with FIACS and interactional level results. They said that the most effective way to teach students speaking is to encourage them to speak the language a lot. So to help them they give a lot of various speaking tasks to do in pair, group and individually.

\section{Findings, Conclusions, and Recommendations}

\section{Findings}

Both teachers devoted class time to talk averagely $77 \%$ which was highly dominant the daily speaking lessons. The FIAC System results showed that 66.51 and 33.84 were teacher and student talk on each categories. The findings show that while the interaction occurs in all classes in response to verbal questions asked, the interaction levels vary from one to the other. Scholars argue that teachers in EFL classes ask more display questions than referential questions (Ellise, 1994). However, this observation reached the opposite result: that the teacher asked more confirmation checks and clarification requests than display questions. This shows that there exists the possibility of discrepancies in our practices. The findings from the extracts results showed that one of the teachers provided negative feedback when he accept students feeling and encourage the students. Teachers were asked several questions before and after the observation the results from the analysis showed that there is a big mix-up on accuracy and fluency, preparation of speaking skills inputs and process. During the researcher observational experience and data analysis, the following findings were also matched with the empirical studies:

$\begin{aligned} \text { i. } & \text { Interactive speaking(semi) } \\ \text { ii. } & \text { Type } \mathrm{C} \text { activities focus on fluency. } \\ \text { iii. } & \text { Teaching talk as interaction }\end{aligned}$

\section{Conclusions}

The interaction was still dominated by the teachers as shown from the observation and recording. The speaking skills input and process haven't been found to have a positive change on their students speaking performance or improvement. It can be concluded that the teachers were not able to use the appropriate type of classroom language and provide formative feedback that really help in improvement of student's language learning.

\section{Recommendations}


First and foremost, modeling a problem. It would also be very helpful to realize learners need lots and lots of practice and encouragement by speaking in range of contexts, and balancing accuracy and fluency. Training on Classroom English and Teaching ideology since it determines teaching behavior (Inputs \&Process). Teachers should contemplate whether too much teacher talk fulfills the predetermined goals of a course or not; if it doesn't, they should probably listen more and talk less/TTT-STT/. Improve classroom interaction and activate students' initiative thinking. Enhance students' subjectivity in classroom learning

\section{References}

Ali, D. \& Savaş, Y. (2013). Pre-Service English Teachers' Beliefs on Speaking Skill Based on Motivational Orientations. English Language Teaching, 6(7),88-95. Retrieved from http://dx.doi.org/10.5539/elt.v6n7p88 on April 3, 2018.

Boonkit, K. (2010). Enhancing the Development of Speaking Skills for Non-Native Speakers of English. Procedia Social and Behavioral Sciences, 2(2010), 1305-1309.

Cheng, Y., Horwitz, E., \& Schallert, D. (1999). Language Anxiety: Differentiating Writing and Speaking Components. Language Learning Journal, 49(3), 417-446.

Creswell, J. (2012). Educational Research: Planning, Conducting, and Evaluating Quantitative and Qualitative Research. (4 ${ }^{\text {th }}$ ed.). Boston: Pearson.

Fasil Demise. (1992). Communicative Strategies Employed by Senior High School Students in Oral Production of English. (MA Thesis). Addis Ababa University.

Haliday, M. A. K. (1990). Spoken and Written Language. Oxford. Oxford University Press

Harmer, J. (2007). The Practice of English Language Teaching. Harlow: Longman.

Hedge, T. (2000). Teaching and Learning in the Language Classroom. Oxford: Oxford University Press.

Hinkel, E. (2006). Current perspectives on teaching the four skills. Tesol Quarterly, 40(1), 109-131. Retrivved from http://www.jstor.org/stable/40264513 on 27-04-2018 17:19 UTC.

Holland, R. and T. Shortall. (1997). Classroom Research and Research methods. Birmingham: The Center for English Language Studies. Retrieved from

Lambert, V. A., \& Lambert, C. E. (2012). Qualitative Descriptive Research: An Acceptable Design. Pacific Rim International Journal of Nursing Research, 16(4), 255256.

Littlewood, W. (2007). Communicative Language Teaching. Cambridge: Cambridge University Press

Nunan, D. (1995). Language Teaching Methodology: A Textbook for Teachers. NY: Phoenix Ltd.,

Nunan, David. (2003). Practical English Language Teaching, McGraw-Hill, NewYork

Park, H., \& Lee, A. R. (2005). L2 Learners' Anxiety, Self-confidence, and Oral Performance. Proceedings of the 10th Conference of Pan-Pacific Association of Applied Linguistics (pp. 107208). Edinburgh University.

Puspasari. 2010. An Analysis on the Speaking Classroom Interaction at the Sixth Year of SD N 2 Mojosongo Boyolali in 2010/2011 Academic Year. Unpublished Research Paper. Surakarta: Muhammdyah University of Surakarta

Richard J. C. and Lockart, C. (1996). Reflective teaching in second language classrooms. New York: Cambridge University Press

Richards, J. (2001). Teaching Listening and Speaking: From Theory to Practice. New York: Cambridge University Press.

Richards, J. C. (1990). Conversationally Speaking: Approaches to the Teaching of Conversation. In Jack. C. Richards. The Language Teaching Matrix. New York: Cambridge University Press. 6785.

Richards, J. C. (2008). Teaching Listening and Speaking: From Theory to Practice. New York: Cambridge University Press.

Stoddart, J. (1986). The Use and Study of English in Ethiopian Schools. Addis Ababa.

Thornbury, S. (2005). How to Teach Speaking. New York: Longman.

Tsou, W. (2005). Improving Speaking Skills through Instruction in Oral Classroom Participation. Foreign Language Annals, 38(1), 46-55. 
Ur, P. (1996). A Course in Language Teaching: Practice and Theory. Cambridge: Cambridge University Press.

Urrutia León, W., \& Vega Cely, E. (2010). Encouraging Teenagers to Improve Speaking Skills through Games in a Colombian Public School, PROFILE, 12(1), 11-31. Bogotá, Colombia. 